the prothorax, the smaller size, etc., separate the present species from Dapsiloderus terminalis. The specimens with very slightly widened anterior tarsi and a longer apical joint to the maxillary palpi are assumed to be males. The palpi are wholly flavous in all but one of the examples before me. The Penang examples are taken as the types.

$$
\text { 2.-Dapsiloderinus notaticollis, n. sp. }
$$

Very elongate, narrow, opaque; black, the prothorax with a transverse rufous spot or patch on each side of the disc before the base, the elytral humeri indeterminately rufescent, the palpi flavous, the tips of the tarsi testaceous; clothedisith extremely fine pruinose pubescence ; the entire surface very densely, minutely punctulate, the minute punctures on the elytra transversely confluent, the base of the latter strongly transversely asperate. Antennae long, joints 3-10 extremely broad, serrate, sub-equal in length, 11 narrower than 10 . Prothorax broader than long, the sides rounded anteriorly and sub-parallel towards the base, the latter bisinuate, the hind angles rather obtuse, the disc foveate in the middle before the base. Elytra without definite costae, the suture closely, transversely asperate towards the apex. Length $6 \frac{4}{5}-7 \frac{1}{4}$, breadth $1 \frac{1}{2}-1 \frac{3}{5} \mathrm{~mm}$. ( $q$ ?)

Hab. : Bonneo, Mt. Matang, W. Sarawak (G. E. Bryant).

Two specimens: one captured in December, 1913, the other in February, 1914. Separable from the variable D. quadricostatus, which has been taken by $\mathrm{Mr}$. Bryant at the same locality, by the noncostate elytra end the entirely black body - the two red spots on the prothorax and the faint reddish humeral patch excepted. It is scarcely possible that $D$. notaticollis can be the $q$ of $D$. quadricostatus?

(To be continued.)

\title{
ON THE CORRECT NAMES OF SOME COMMON
}

\section{BRITISH DIPTERA.}

BY F. W. EDWARDS, B.A., F.E.S.

(Published by permission of the Trustees of the British Museum.)

In studying the works of the older entomologists, one cannot but be struck by the contrast between the two schools: the real naturalists, such as Réaumur and De Geer, and the mere nomenclators, such as Linné, Fabricius, and Meigen. The latter, no doubt, did a most useful work, but it is to the former that we have to turn for information concerning the life-histories of insects. The latter do not seem to have been interested in these aspects of their science, and although they frequently adopted the names of the former, they were often, through 
insufficient knowldege or mere carelessness, incorrect in their application of them; not a few of these mistakes have been handed down for generations until some person has been enterprising enough to consult the original author's work.

In Diptera there are a number of such instances. Thus De Geer's Tipula culiciformis was for long assumed to be a species of Corethra, but is now known to be the same as Mochlonyx velutinus. The purpose of the present note is to call attention to three more cases which have apparently been overlooked. Unfortunately, these affect the names of four of our commonest British Diptera, but as the changes will have to be made some day, they had better take place now. It is, moreover, some compensation for the inconvenience caused, to reflect that for once the Law of Priority has brought belated justice to a really sound naturalist.

\section{1.-Tipula fungorum De Geer. (Mém., Tome VI, p. 361).}

De Geer found some Dipterous larvae, in a fungus (Boletus luteus), which he described and figured, but failed to rear. In the following year he found larvae again in the same species of fungus, and hatched flies from them. Naturally he assumed that he had dealt with only one species, to which he gave the name Tipula fungorum. Later on Meigen had an insect which he thought to be the same as De Geer's, but for which he proposed the name Mycetophila fusca. Fifty years later Winnertz included what he considered to be the same species in the genus Exechia, restoring to it De Geer's name of fungorum, and recently $E$. fungorum has been selected by Johannsen as the type of the genus Exechia.

Now in the light of our present knowledge, it is clear that $(a)$ the larva figured by De Geer is that of a Bolitophila, as shown unmistakeably by the large antennae; (b) the fly described by De Geer is our Mycetophila punctata, as shown both by the general description, and the figure (quite recognisable) of the male genitalia; (c) Meigen's $M$. fusca was a totally different inseet, he being apparently misled by an inaccuracy in De Geer's figure of the wing: $M$. fusca is doubtless an Exechia, perhaps, as Meigen describes the thorax as having three black stripes, the same as the species we know as E. trivittata, though only an examination of the type can settle this; (d) Winnertz's Exechia fungorum was a different insect again, clearly not the same as Meigen's $M$. fusca, since the thorax is unstriped, and certainly not at all related to De Geer's T. fungorum. 
The first question which arises is whether De Geer's name should be used for his larvae or for his adults. The former were, no doubt, described first, but as he was unable to assign them definitely to a genus without rearing them, and as his diagnosis is based on the adult, I consider that the name must apply to the latter. Our Mycetophila punctata $\mathrm{Mg}$. (1804) must therefore be known in future as Mycetophila fungorum (De Geer, 1776).

With regard to our Exechia fungorum, according to the views of some writers, the fact that this name has been used for the type-species of Exechia should now necessitate the placing of Exechia as a synonym of Mycetophila. I cannot agree with this view, however, and consider that the species which should be regarded as the type of Exechia is the one which Winnertz actually had under the name fungorum, not the one to which this name was originally applied. As stated above, the name $M$. fusca is not applicable to this species, although it is usually placed as a synonym; nor according to our catalogue is there any other name which can be used for it. I do not, however, think it is necessary to propose a new name, as I believe Meigen's Mycetophila guttiventris is really our species. This has usually been classed as a synonym of Exechia lateralis, and so it may possibly be, the females of the two, which were all that Meigen possessed, being very difficult to distinguish. However, unless or until Meigen's type can be examined, I think it will be best to follow Lundstroem's interpretation of $M$. lateralis, and to use the name guttiventris for the Exechia fungorum of Winnertz and later writers.

\section{2.-Tipula stercoraria De Geer (Mém., Tome. VI, p. 388).}

De Geer, who bred this species from larvae found in horse-dung, described it as follows: " Entirely a beautiful dull black, but the wings are milk-white, and the anterior barbs of the beautiful plumose male antennae are whitish, while those nearest the head are black." $\mathrm{He}$ also gave figures which showed the species to belong to the Orthocladius group of the Chironomidae, and stated that it was only $1 \frac{1}{2}$ lines long.

T. stercoraria has for long been regarded as a species of Orthocladius, Schiner being apparently the first to describe the venation, and all subsequent authors have followed his interpretation. But no common species of Orthocladius has the outer part of the male antennae whitish, and so far as I am aware no one has ever found Orthocladius larvae in dung, or indeed out of water. On the other 
hand, De Geer's description applies very well indeed to our Camptocladius byssinus, and to no other Chironomid, while several species of Camptocladius are known to be dung or soil feeders in the larval state.* If we suppose that De Geer's measurement of length included the antennae, the only apparent discrepancy practically disappears.

The name Camptocladius stercorarius (De Geer, 1776), must therefore replace that of $C$. byssinus (Schrank, 1803). I cannot say at present what name should be used for the species which is widely known as Orthocladius stercorarius, but it would appear that several closely allied species have been confused under this designation; two such are $O$. novatus (Walker) and $O$. oblidens (Walker), but older names probably exist for both of these.

The remarks made above concerning the status of the genus Exechia apply also to Orthocladius, since O. stercorarius Auct. (nec Deg.) was selected by Coquillett in 1910 as the generic type.

\section{3.-Culex communis De Geer (Mém., Tome VI, p. 316).}

De Geer gives quite respectable figures of the larvae, pupae, and adult of a mosquito which he found near Leussta (? in Sweden). He thought his species was the same as Linnaeus' C. pipiens, the lifehistory of which had been worked out by Réaumur, but he was not quite certain as he had noticed some differences in the larvae, and probably on this account he proposed the name communis as an alternative to pipiens. All subsequent writers down to Theobald have sunk communis as synonymous with pipiens. But it is perfectly evident from De Geer's figures, as well as from the fact that he found full-grown larvae in May, that he was not dealing with C.pipiens at all, but with a species of Ochlerotatus, $\uparrow$ almost certainly our common British O. nemorosus Mg.

There is one point of difference, according to.De Geer's figures, between his species and our $O$. nemorosus $\mathrm{Mg}$. He represents the penultimate joint of the male palpi as being considerably longer than the terminal, whereas in nemorosus the two are almost equal in length. Although I believe this apparent difference is probably due to an error on De Geer's part, it will perhaps save us from the necessity of sinking the name nemorosus, as it is of course possible that there may be in Sweden a species which answers exactly to De Geer's figures.

* On account of its larval habits, Malloch (Bull. Illinois State Lab. Nat. Hist., X, art. VI, May, 1915) has already suggested that C. byssinus is a Camptocladius and not an Orthocladius.

† Attention has been called to the true generic position of $C$. communis by Howard, Dyar and Knab (Mosq. of N. and C. Amer. and W. Indies, Vol. 3, p. 368, Oct., 1915). 


\section{4.-Musca autumnalis De G. (Mém. Tom. VI, p. 83, 1776).}

De Geer gives a short and rather incomplete description of this species, which is nevertheless quite recognisable as applying to the fly generally known as Musca corvina Fab.' Fabricius' name, however, was not published until five years after De Geer's (Species Insectorum, II, p. 440, 1781) ; he not only quotes De Geer's diagnosis and name, but has apparently based his own short description on De Geer's, and is in fact only re-naming the species. He gives no reason for this change, and yet his name has been used by practically every subsequent author, without any question as to its validity. There being no earlier homonym of Musca autumnalis De Geer's name ought to be used, as has been done recently by Howard in his book on the house-fiy. Fortunately, autumnalis is an appropriate name for this fly, which corvina is not. The term "raven-fly," which has recently been invented as a popular name, should be dropped; it is merely a translation of the name corvina, and is neither in common use, nor has it any relevance.

\section{British Museum (Natural History) :}

November 11th, 1915.

British Fossil insects. - In the "Proceedings of the U. S. National Museum," Vol. 49, pp. 469-499, pls. 60-65, dated December 11th, 1915, Mr. T. D. A. Cockerell gives a brief summary of our knowledge of British fossil insects up to the date of writing. The total number of species is 368: Carboniferous 27, Lias 82, Oolite 209, Tertiary 42, Post Tertiary 8. This number includes various (44) new forms described in the same paper, all obtained many years ago, from the Lias or Oligocene, by the Rev. P. B. Brodie, in the Isle of Wight. The duplicates only of this collection (from that of Lacoe) have been examined by Mr. Cockerell, the first set being contained in the British Museum. The new genera and species described are as follows: Lias insECTs-ORTHOPTERA [Eospilopteron (n. gen., with n. fam. Eospilopteronidae) ornatum, Locustopsis lacoei, Haglopsis brodiei]; Neuroptera [Nematophlebia (n. gen. Sialidae) plicata]; Palanohemiptera [Meshemipteron (n. gen.) incertum]; Coleoptera [Protocuneus (n. gen., ? Rhynchophora) punctatus, Elaterophanes acutus, Pseudotelephorus punctulatus and grandis, Phanerogramma (n. gen., ? Tenebrionidae), for Akicera heeri Giebel, Holcoptera confluens, Glaphyroptula anglica]: OLIGOCENE INSECTS-HyMENOPTERA [Philoponites (n. gen. Philanthidae) clarus, Aneurhynchus (n. gen. Diapriidae) conservatus, Ponera hypolitha, Dolichoderus britannicus, anglicus, ovigerus, Leptothorax gurnetensis, Oecophylla atavina, perdita, megarche]; НомортекA [Necropsylla anglica, Psylla exhumata, Schizoneurites (n. gen. Aphididae) brevirostris]; Diptera [Culex protolepis, protorhinus, petrifactellus, Paltostomopsis 


\section{$2 \mathrm{BHL}$ Biodiversity Heritage Library}

Edwards, F W. 1916. "On the correct names of some common British Diptera." The Entomologist's monthly magazine 52, 59-63.

https://doi.org/10.5962/bhl.part.23929.

View This Item Online: $\underline{\text { https://www.biodiversitylibrary.org/item/35890 }}$

DOI: https://doi.org/10.5962/bhl.part.23929

Permalink: https://www.biodiversitylibrary.org/partpdf/23929

\section{Holding Institution}

Smithsonian Libraries

\section{Sponsored by}

Smithsonian

\section{Copyright \& Reuse}

Copyright Status: NOT_IN_COPYRIGHT

This document was created from content at the Biodiversity Heritage Library, the world's largest open access digital library for biodiversity literature and archives. Visit BHL at https://www.biodiversitylibrary.org. 